\title{
UNDERSTANDING AND QUALITY CONTROL THROUGH A NEW PRODUCT
}

ISSN 1857-9973

658.62:658.56

\section{Elenica Sofijanova', Darko Andronikov ${ }^{2}$, Dragana Lazarova ${ }^{3}$}

${ }^{1}$ „Goce Delcev“University- Faculty of Economics - Stip, Republic of Macedonia, elenica.sofijanova@ugd.edu.mk

${ }_{2}^{2}$, Goce Delcev“University Faculty of Technology - Stip, Republic of Macedonia, darko.andronikov@ugd.edu.mk

${ }^{3}$, MAKPROGRES LTD” Quality Control - Vinica, Republic of Macedonia, dragana.lazarova@live.com

\begin{abstract}
Quality is often used to signify 'excellence' of a product or service. Quality and reliability, comes back the answer. The two are used synonymously, often in a totally confused way. Clearly, part of the acceptability of a product or service will depend on its ability to function satisfactorily over a period of time, and it is this aspect of performance which is given the name reliability. It is the ability of the product or service to continue to meet the customer requirements. Reliability ranks with quality in high level of importance, since it is a key factor in many purchasing decisions where alternatives are being cosidered. Many of the general management issues related to achieving product or service quality are also applicable to reliability. The requirements are of paramount importance in the assesment of the quality of any product or service, and quality is the most important aspect of competitiveness.
\end{abstract}

Key words: quality, reliability, general management, innovative product, competitiveness, customer requirements

\section{Introduction}

The quality of any good or service is the most important aspect as a whole. Quality needs to be managed, it cannot happen by itself. Motivation is a key factor when it comes to quality. Quality is often used to identify efforts to produce a good or service. Quality is sometimes synonymous with pelativity. The acceptance part of the products or services depends on the functional satisfaction for a certain time, and this aspect of performance that is given, creates the name relativity. 


\section{Design and conformance}

To understand how quality may be built into a product or service, at any stage, it is necessary to examine the two distinct, but inter - related aspects of quality:

- Quality of design

- $\quad$ Quality of conformance to design[1]

Quality of design is a measure of how well the product or service is designed to achieve its stated purpose. The beautifully presented gourmet meal will not necessarily please the recipient if he or she is travelling on the highway and stopped for a quick bite to eat. The most important feature of the design, with regard to achieving quality, is the specification. Specifications must also exist at the internal supplier / customer interfaces to pursue company - wide quality.

The financial controller must issue a specification of the information he or she needs, and when, to ensure that foreign exchange rate fluctuations do not cropplr the company's finances. The business of sitting down and agreeing a specification at every interface will clarify the true requirements and capabilities. It is the vital first stage for a successful total quality effort.

\subsection{Innovative product and services}

Companies often announce "new" or "innovative" products and services, and often describe some of their market offerings as "dramatic"," or use similar exaggerations.[2] Not with standing the above, an innovative product does not have to be a novelty for the whole market in order to continue to be considered innovative. It is enough that it is a novelty for the target market segment, or for the bidder (company). All levels at which a product can be considered "new" fall into different categories.

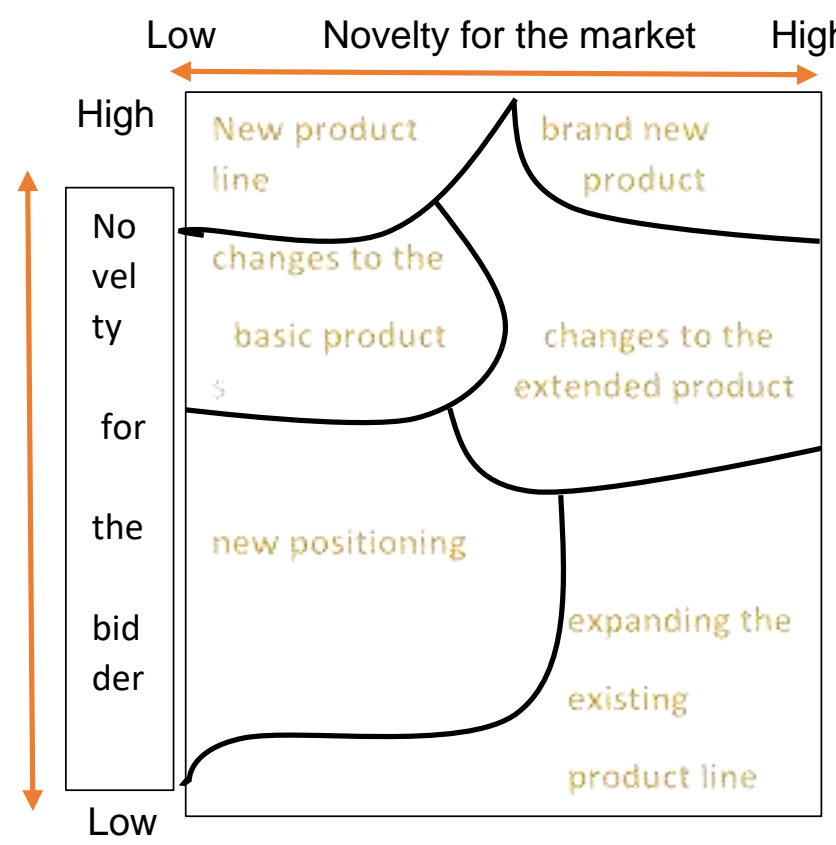

\footnotetext{
${ }^{1}$ One of the best approaches of this kind when introducing a new product was created by Steve Jobs, at the presentation of the new Apple iPad tablet: "We are excited that our customers can finally get to this magical and revolutionary product..."
} 
Figure 1: Innovative product (How new is the new product or service?)

Only about $10 \%$ of the product is a complete novelty, based on radical innovation and creating a whole new market (such as Sony's Walkman in the 1980s, as the first personal, portable device for listening to music on the go). The next $20 \%$ of the product is new to its provider: although, perhaps, Steve Jobs thought tablets were a radical novelty, they existed before Apple's iPad. Nearly a quarter of product innovations can be related to the expansion of existing product lines, or somewhat altered old products. The rest of the innovation is mainly reduced to the market repositioning of old products to new market segments, usually with a lower price, in order to "revive" mature products, which have become insufficiently attractive to more attractive market segments.

With regard to the acceptance of innovations, it is necessary to discuss how innovative products are spread, ie how customers accept them. Namely, only a minority (up to a maximum of $3 \%$ ) of customers are ready to accept completely new products, which also create completely new markets (and pay a high price for them). As the product approaches its maturity, it will attract additional customer groups. However, mature products are losing customers from the groups of innovators and early adopters, who are looking for new, modern products, so older products need to be (re) positioned on the market.

Traditional marketing has developed a detailed theoretical framework for new product development. It usually consists of a series of steps, and each of them involves a final decision on further investing (and continuing to develop) a potential new product [3]:

$\checkmark$ Discovering and creating ideas for new product development;

$\checkmark$ Description of the proposed new product and its properties;

$\checkmark$ Preparation of a summary of the business case of a new product (business case), document or presentation, which (a) serves to explain or persuade to launch a new project, linking the benefits of the new product with the business needs of the organization and / or its market opportunities [ 4];

$\checkmark$ Development of technology needed to make a new product and build a prototype;

$\checkmark$ Checking the technical feasibility of a prototype and its market testing (using market research techniques);

$\checkmark$ Product introduction;

However, the traditional process of developing a new product is not always beneficial for new entrepreneurs, which can be justified by a number of arguments. The most obvious of these are the size and strength of existing companies, which have stable customer groups and old products and services, on the basis of which they can develop successful (traditional) market research.

Therefore, they can relatively easy create complete specifications for new or improved products and services and follow all the prescribed stages of development. Such companies, obviously, have enough resources and income to survive the collapse of some new product. On the other hand, the development of a new product, which does not meet the needs of customers well enough, for a small company, which depends on a single product, or a production line, can also mean the end of an entrepreneurial venture.

This is the fundamental reason why Eric Ries, the author of the "lean startup" approach to starting a new business [5], recommends an approach to the development of a Minimum Viable Product (MVP). In principle, it is a demonstration of a future product or service, which shows the most important properties and provides the entrepreneur (s) with the opportunity to collect feedback from future customers [6]. This approach can be used to assess whether the intended product has market potential and how to improve it (if such potential exists at all). In 
this way, one of the most significant mistakes in establishing a new entrepreneurial venture is removed, which is associated with "blind falling in love" with the entrepreneurial idea and a significant overestimation of the interests of potential customers.

Nevertheless, there are many approaches and tools for objectively assessing entrepreneurial ideas, and the described minimal product approach is one of them. However, regardless of all approaches, the future entrepreneur should be confident in his assessment of meeting the needs of the target market segment, which is not possible without prior (at least simple) market research.

\section{Bread consumer analysis}

A research was done in a bakery in which, in addition to the usual quality products, a new product was started to be sold - New oil bread. Bread is part of the basic ingredients in the diet. It is prepared by baking, steaming or frying dough that mostly consists of flour and water. Salt is often needed, and yeast is often used. Some types of bread also contain spices and grains such as sesame and poppy seeds that can be used for decoration.

Table 1: Value at wich products are sold in the bakery

\begin{tabular}{ccc}
\hline A Serial Number & Product & Price \\
\hline 1. & Homemade bread on wood & 17 denars \\
\hline 2. & New bread on oil & 15 denars \\
\hline 3. & Small bread & 8 denars \\
\hline 4. & Cottage cheese pie & 12 denars \\
\hline 5. & Pizza pastry & 13 denars
\end{tabular}

Table 2: Products delivered in the period from 24.04.2018 to 30.04 .2018

\begin{tabular}{|c|c|c|c|c|c|c|c|c|}
\hline $\begin{array}{l}\text { A Serial } \\
\text { Number }\end{array}$ & Product & $\begin{array}{c}24.04 . \\
2018\end{array}$ & $\begin{array}{c}25.04 . \\
2018\end{array}$ & $\begin{array}{c}26.04 . \\
2018\end{array}$ & $\begin{array}{c}27.04 . \\
2018\end{array}$ & $\begin{array}{c}28.04 . \\
2018\end{array}$ & $\begin{array}{c}30.04 \\
2018\end{array}$ & Total \\
\hline 1. & $\begin{array}{c}\text { Homemade } \\
\text { bread on wood }\end{array}$ & 3019 & 2995 & 3038 & 3062 & 3997 & 4002 & 20113 \\
\hline 2. & $\begin{array}{c}\text { New bread on } \\
\text { oil }\end{array}$ & 4229 & 4377 & 4481 & 4571 & 6249 & 5974 & 29881 \\
\hline 3. & Small bread & 368 & 373 & 353 & 353 & 230 & 290 & 1967 \\
\hline 4. & $\begin{array}{c}\text { Cottage } \\
\text { cheese pie }\end{array}$ & 376 & 349 & 375 & 360 & 265 & 306 & 2031 \\
\hline 5. & Pizza pastry & 67 & 64 & 68 & 70 & 17 & 40 & 326 \\
\hline 6. & Total & 8059 & 8158 & 8315 & 8416 & 10758 & 10612 & 54318 \\
\hline
\end{tabular}


From the table view it can be concluded that the home-made bread baked on wood is sold at the highest price of 17 denars, while the new oil bread is available at a price of 15 denars. In the period of 6 days, the new oil bread with a total of 29881 pieces was mostly brought to the market. The market representation is rapidly increasing every day, compared to the previous one, which can be concluded from the figures shown in Table 2. The make or buy decision refers to the problem encountered by an organization when deciding whether a product or service should be purchased from outside sources or generated interlay.

Often make or buy decisions and the suppliers are based on price, but this is a dangerous criterion with which to evaluate these strategic decisions. The lowest price may not necessarily be that which is least costly to the purchasing organization, since it may attract other costs of correcting, sorting out, chasing-up, etc. These increase the total cost of the purchase, and that is a far more useful criterion.

Table 3: Percentage and cumulative value of exported products

\begin{tabular}{cccc}
$\begin{array}{c}\text { A Serial } \\
\text { Number }\end{array}$ & Exposed products & $\%$ part & Cumulative value \\
\hline 1. & Homemade bread on wood & $37,02 \%$ & 37,02 \\
\hline 2. & New bread on oil & $55,01 \%$ & 92,03 \\
\hline 3. & Small bread & $3,62 \%$ & 95,65 \\
\hline 4. & Cottage cheese pie & $3,74 \%$ & 99,39 \\
\hline 5. & Pizza pastry & $0,60 \%$ & 99,99 \\
\hline
\end{tabular}

The percentage of cumulative value of the presented values varies on all five products that are present on the market, on the new oil bread the share expressed in percent is $55.01 \%$, and the cumulative value is 92.03 units. These values are also represented through the Pareto diagram. 
Table 4. Pareto diagram of delivered products

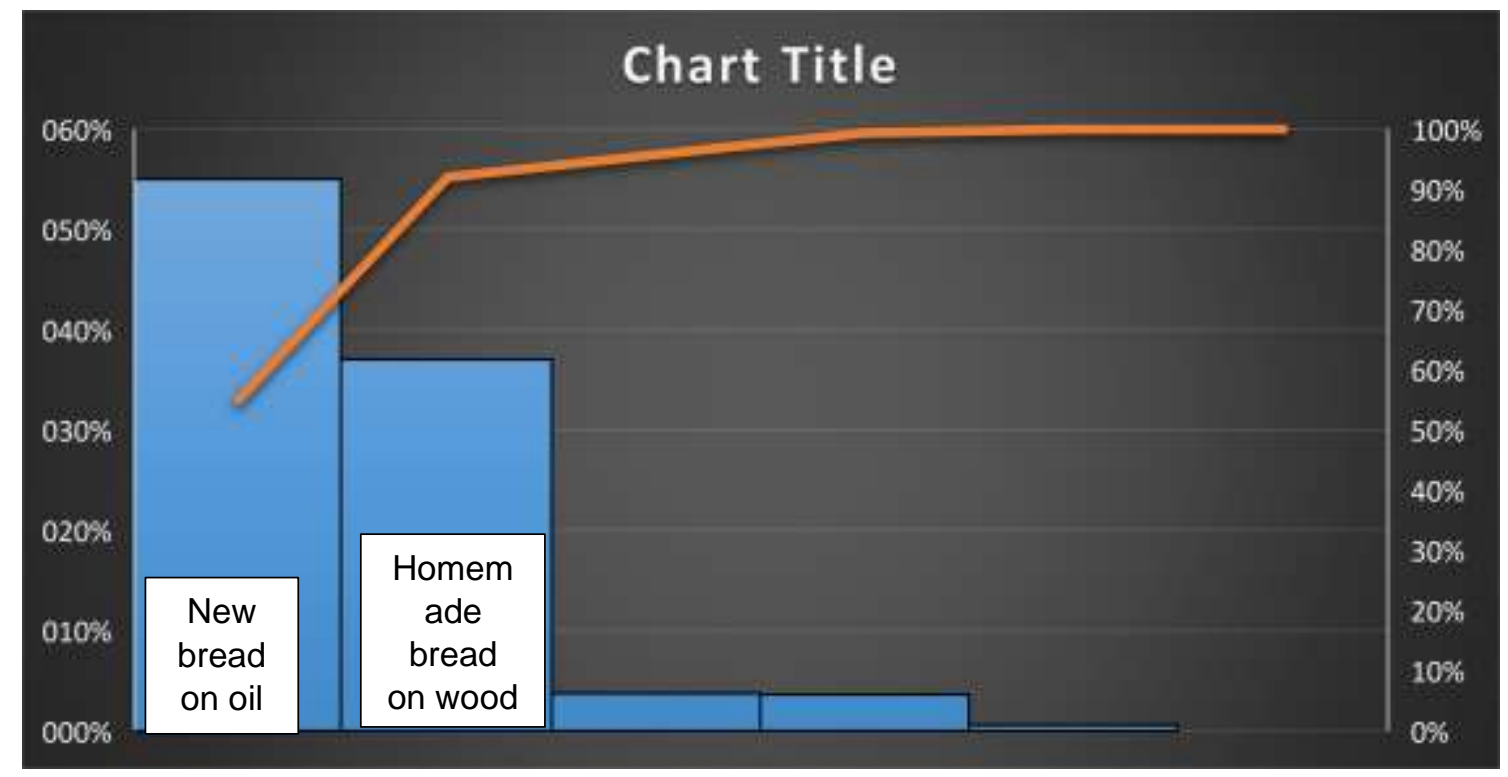

Table 5: Returned products in the period from 24.04.2018 to 30.04.2018

\begin{tabular}{|c|c|c|c|c|c|c|c|c|}
\hline $\begin{array}{l}\text { A Serial } \\
\text { Number }\end{array}$ & Product & $\begin{array}{c}24.04 . \\
2018\end{array}$ & $\begin{array}{c}25.04 . \\
2018\end{array}$ & $\begin{array}{c}26.04 . \\
2018\end{array}$ & $\begin{array}{c}27.04 . \\
2018\end{array}$ & $\begin{array}{r}28.04 . \\
2018\end{array}$ & $\begin{array}{c}30.04 . \\
2018\end{array}$ & Total \\
\hline 1. & $\begin{array}{l}\text { Homemade } \\
\text { bread on } \\
\text { wood }\end{array}$ & 500 & 417 & 449 & 319 & 14 & 127 & 1976 \\
\hline 2. & $\begin{array}{c}\text { New bread on } \\
\text { oil }\end{array}$ & 640 & 638 & 540 & 308 & 301 & 181 & 2608 \\
\hline 3. & Small bread & 30 & 28 & 29 & 11 & 10 & 5 & 113 \\
\hline 4. & $\begin{array}{c}\text { Cottage } \\
\text { cheese pie }\end{array}$ & 22 & 43 & 29 & 30 & 1 & 10 & 135 \\
\hline 5. & Pizza pastry & 12 & 18 & 12 & 10 & 2 & 0 & 54 \\
\hline 6. & Total: & 1204 & 1144 & 1059 & 678 & 478 & 323 & 4886 \\
\hline
\end{tabular}


Table 6: Estimated share and cumulative value of returned products

\begin{tabular}{cccc}
\hline $\begin{array}{c}\text { A Serial } \\
\text { Number }\end{array}$ & Product & $\%$ part & Cumulative value \\
\hline 1. & Homemade bread on wood & $40,44 \%$ & 40,44 \\
\hline 2. & New bread on oil & $53,37 \%$ & 93,81 \\
\hline 3. & Small bread & $2,31 \%$ & 96,12 \\
\hline 4. & Cottage cheese pie & $2,76 \%$ & 98,88 \\
\hline 5. & Pizza pastry & $1,11 \%$ & 99,99 \\
\hline
\end{tabular}

From the comparative analysis, it is very logical that the largest number of returned products is on the new oil bread, because it was present in the largest number of pieces on the market. The percentage share and the cumulative value is $53.37 \%$ or 93.81 units.

Table 7. Pareto diagram of returned products

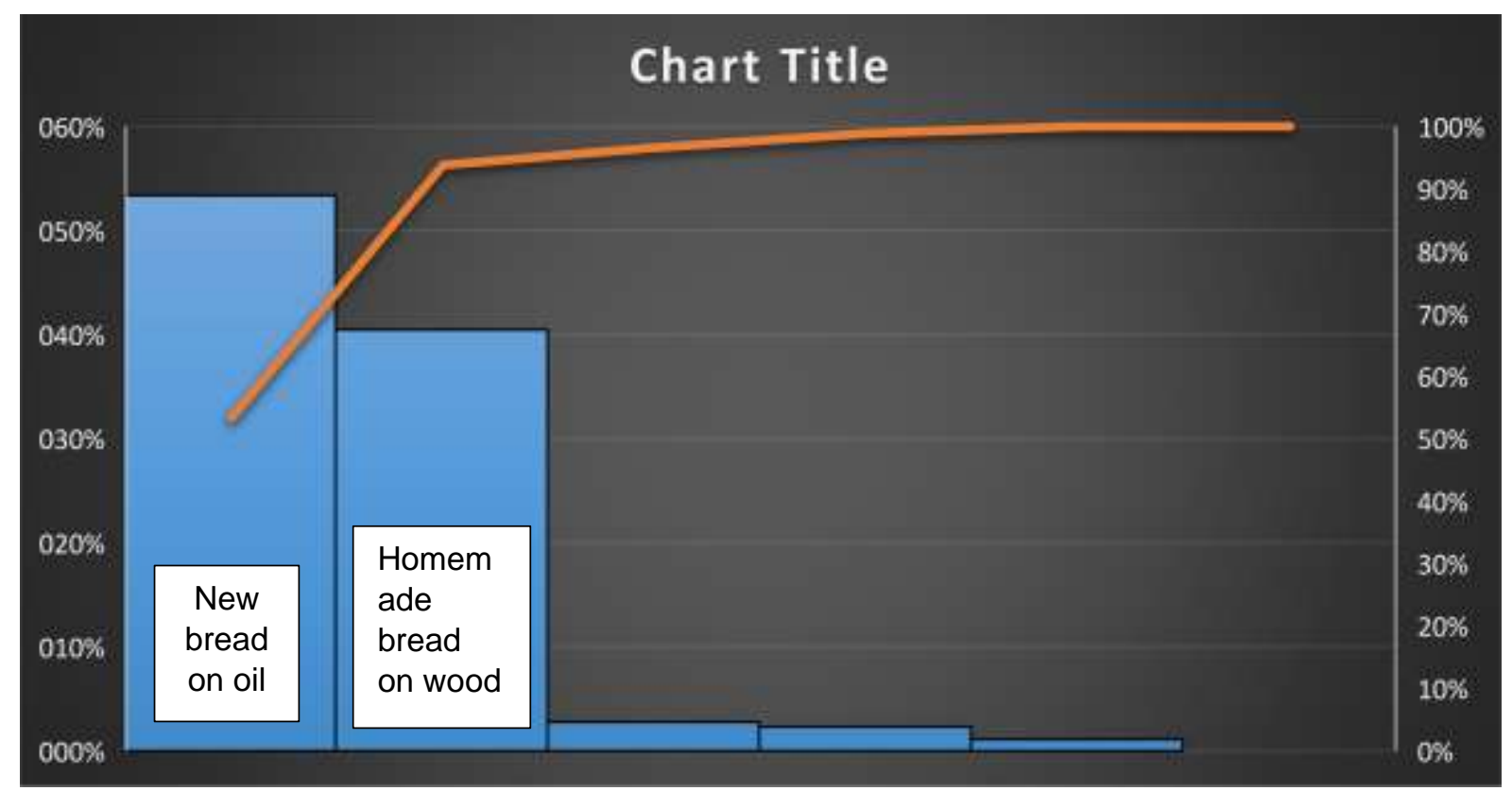


Table 8. Totally exported products

\begin{tabular}{|c|c|c|c|c|c|c|c|c|}
\hline $\begin{array}{l}\text { A Serial } \\
\text { Number }\end{array}$ & Product & $\begin{array}{c}24.04 . \\
2018\end{array}$ & $\begin{array}{c}25.04 . \\
2018\end{array}$ & $\begin{array}{c}26.04 . \\
2018\end{array}$ & $\begin{array}{c}27.04 . \\
2018\end{array}$ & $\begin{array}{c}28.04 . \\
2018\end{array}$ & $\begin{array}{c}30.04 . \\
2018\end{array}$ & Total \\
\hline 1. & $\begin{array}{c}\text { Homemade } \\
\text { bread on wood }\end{array}$ & 2519 & 2578 & 2589 & 2743 & 3833 & 3875 & 18137 \\
\hline 2. & New bread on oil & 3589 & 3739 & 3941 & 4263 & 5748 & 5793 & 27073 \\
\hline 3. & Small bread & 338 & 345 & 324 & 342 & 220 & 285 & 1854 \\
\hline 4. & $\begin{array}{c}\text { Cottage cheese } \\
\text { pie }\end{array}$ & 354 & 306 & 346 & 330 & 264 & 296 & 1896 \\
\hline 5. & Pizza pastry & 55 & 46 & 56 & 60 & 15 & 40 & 272 \\
\hline 6. & Total & & & & & & & 49232 \\
\hline
\end{tabular}

The highest income was realized exactly from the new product, the new oil bread, 406,095 denars, and the least from the pizza pastry, 3536 denars.

Although the price is not low, the need of consumers shows that they need innovative, new products, with new flavors prepared according to new recipes.

These needs should not be substitutes, on the contrary, they should be an incentive and motivation for manufacturers for more inventiveness and creativity.

Table 9: Weekly revenue of imported products

\begin{tabular}{cccc}
\hline A Serial Number & Product & $\begin{array}{c}\text { Total set out for 6 } \\
\text { days }\end{array}$ & Earnings (denars) \\
\hline 1. & $\begin{array}{c}\text { Homemade baked } \\
\text { bread (MKD 17) }\end{array}$ & 18137 & 308.329 den. \\
\hline 2. & New bread (15 den.) & 27073 & 406.095 den. \\
\hline 3. & Small bread (8 den.) & 1854 & 14.832 den. \\
\hline 4. & Cottage cheese pie & 1896 & \\
\hline & $(12$ den.) & & 3536 den. \\
\hline 5. & Pizza pastry \\
& $(13$ den.) & 272 & 755.544 den. \\
\hline 6. & Total & & \\
\hline
\end{tabular}


According to the analysis we made for these 5 products, we came to the conclusion that the most exported products are on April 28, 2018, and the least on April 24, 2018. Most returned products are on April 24, 2018, and the least on April 30, 2018.

From the analysis we noticed that the new bread on oil is consumed the most. The income for these 5 products from 24.04 .2018 to 30.04 .2015 is 755,544 denars, and the loss is 75,938 denars.

So, purchasing is an important feature of just-in time methods of inventory control. The development of long-term relationships with a few suppliers, rather than short-term ones with many, leads to the concert of coproduces in networks of trust providing dependable quality and delivery of goods and services.

\section{Conclusion}

Quality is a property which may change with the age of the product or service. Although purchasing is clearly an important area of managerial activity,it is often neglected by both manufacturing and service industries.

The separation of purchasing from selling has, however, been removed in many large retail organizations, which have recognized that the purchaser must be responsible for the whole product line - its selection, quality, specification, delivery, price, acceptability, and reliability. But, every product will eventually fail, although in some cases the possibility is small enough for the product to be effectively infinitely reliable.

With the pressures to reduce cost, and with the need for increasing complexity, the probability of a product or service failing within the user's anticipation of its working life is likely to be finite. As reliability is an exceedingly important aspect of competitiveness, there is a need to plan and design reliability into products and services. Unfortunately, the testing of a desing to assess its reliability is difficult, sometimes impossible, and the designer must therefore invest in any insurance which is practicable.

Clearly, part of the acceptability of a product will depend on its ability to function satisfactorily over a period of time. This aspect of performance has been given the name reliability, which is the ability to continue to be fit for the purpose or meet the customer requirements.

\section{References}

[1] Johan S Oakland, Total Quality Management, Heinemann Professional Publishing, New York, 1989, p.94 - 120

[2] http://www.apple.com/pr/library/2010/03/05iPad-Available-in-US-on-April-3.html

[3] Garcia, R.: Creating and Marketing New Products and Services, CRC Press/Taylor \& Francis, Boca Raton, 2014, str. 7 - 17.

[4](https://en.wikipedia.org/wiki/Business case), (http://www.wikihow.com/Write-a

Business-Case)

[5] http://theleanstartup.com/principles

[6] https://leanstack.com/minimum-viable-product/ 
[7] https://www.google.com/url?sa=t\&rct=i\&q=\&esrc=s\&source=web\&cd=\&cad=ria\&uact= 8\&ved=2ahUKEwjRmcLw16bsAhVSCwKHTYKD3IQFjABegQIARAC\&url=http\%3A\%2F \%2Fe-learning.efst.unist.hr\%2Fhr\%2Fcourses\%2Fmarketing-innovative-products-and-

services\%2F9369-razvoj-novog

proizvoda\%2F\&usg=AOvVaw0DyF5MGsKinxDjN5grAYLa

[8] Deming Walter E. Quality, Productivity, and Competitive Position, MIT Centre for Advanced Engineering Study, Cambridge, Mass, 1982

[9] Juran Joseph M.Gruna F M.Quality Planning and Analysis $2^{\text {nd }}$, New York: McGraw Hill Book Company, 1980 